Article

\title{
Auditing Marketing and the Use of Social Media at Ski Resorts
}

\author{
Teodoro Luque Martínez ${ }^{(}$, Luis Doña Toledo* and Nina Faraoni
}

Marketing and Market Research Department, Faculty of Economics and Business, University of Granada, 18071 Granada, Spain; tluque@ugr.es (T.L.M.); ninafaraoni@correo.ugr.es (N.F.)

* Correspondence: luisdt@ugr.es

Received: 18 February 2019; Accepted: 14 May 2019; Published: 20 May 2019

\begin{abstract}
Mountain and snow tourism are sectors of immense social and economic importance that are developed in an especially sensitive environmental context. A large part of this tourism is channeled through ski resorts. The literature on comparative studies of ski-resort management and, in particular, on marketing management, is limited. This study contributes knowledge on the application of marketing practiced at ski resorts. For the first time, an audit of marketing at ski resorts is performed through a quantitative survey at resorts in two countries (Spain and Italy). The importance-performance analysis (IPA) is used, which identifies both the strong and the weak points and the great deficits of marketing management at ski resorts from the perspective of their directors, to whom the questionnaire was addressed. The social media usage of the ski-stations is also analyzed, identifying different typologies of resorts in accordance with their performance against 11 indicators from Twitter and 15 from Facebook. Knowing the opinion of the visitors, the online and competitive strategy, and adapting to the legislative changes are the aspects to which the directors attach greater importance. The greatest deficits were linked to employee motivation and communication (internal and non-integrated). There are minor differences in Twitter and Facebook indicators between Spanish and Italian ski resorts. The turnover results of the ski resorts present more correlation with Facebook indicators than with Twitter ones. This analysis provides recommendations and implications for the management of ski resorts in the six dimensions of marketing under consideration. It, likewise, offers knowledge of the social-media-related behavior of resorts that are leaders on both Twitter and Facebook, for benchmarking purposes.
\end{abstract}

Keywords: ski-resort management; ski-resort marketing; ski resorts; audit; mountain tourism

\section{Introduction}

Tourism is a sector of great dynamism that has displayed vigorous growth over many years [1]. Some studies have examined the potential for integration between sport and tourism, which depends on a decisive orientation, the regional context, government policies, and cultural and organizational structures [2]. The strong connection between tourism and sport means that sports tourism is one of the most highly developed segments of tourism. The national and international popularity of sporting events have contributed to that level of development, the benefits associated with active participation in sports, as have the variety of sporting events and their organization with periodic and frequent events in different parts of the world [3].

Ski resorts as tourism destinations are a magnificent example of a symbiosis between tourism and sport $[1,4,5]$. Together, they form an entity with shared interests in which different types of organizations interact (hotels, restaurants, travel agencies, sports firms, and environmental protection agencies, among others) that provide a variety of services to respond to the main driving force: Conducting activities and practicing sports related to snow-and-mountain tourism. Their relevant 
social and economic impacts on the environment dynamize and favor the development of areas of influence, either as the principal activity, or as one that is complementary to others [6,7].

The winter sports industry contributes to the development of tourism and, in a considerable way, to economic growth and territorial organization [8-10]. Over 80 countries from all over the world offer winter sports activities, in all, at approximately 2000 ski resorts. Some have a long tradition in winter sports (for example, France, Switzerland, Austria, and Italy), while others, such as China and Eastern European countries, are emergent destinations [11].

The variety and breadth of the offer in relation to winter sports requires analysis and planning of destination marketing activities. All the more so, if the point of view of the visitor is considered, greater use of marketing tools is necessary in the management of those destinations [12]. Ski-resort managers need to study the potential of their destinations and current markets and prepare proposals that will differentiate them from the competition [13], through strategic analysis [14]. The importance of those destinations makes it advisable to gain an understanding of the behavior and, for example, the attitudes that are determined by the emotions that they awaken [15] and user preferences, and the surrounding environment. The development of innovative communication strategies and the application of positioning and segmentation strategies for visitors, and both amateur and professional skiers, may also be included [1,5,11,16-19].

In short, destination management cannot be understood without a major role for marketing. The question that is now raised is whether that is so and how it is done. Although there are studies on specific aspects of marketing, the academic literature on the application of marketing or the auditing of marketing at ski resorts [20] is practically non-existent. Within it, an aspect of special relevance in the strategy of all organizations, following the expansion of the Internet, is the virtual performance on social media [21] of ski resorts, also with an almost inexistent literature. No studies have been identified that set out to analyze the indicators provided by social media in reference to ski resorts, although their utility in the present-day context is recognized [22].

The main objective of this work is to know the perception that the managers of ski resorts have about the application of marketing management at ski resorts and the analysis of their performance in social networks, in particular:

- To conduct a marketing audit that will identify the main strengths and weaknesses in the application of marketing from the perspective of managers;

- To discover the main deficits in the application of marketing at ski stations and whether they present differences between countries, applying the importance-performance analysis (IPA) with a new methodological validation variant;

- To describe the patterns of behavior on social media (Twitter and Facebook) and to establish whether there are differences in accordance with the country in which the ski resort is found;

- To identify typologies of ski resorts by their patterns of behavior on social media.

In response to those questions, which are raised here for the first time, a survey was administered to directors and representatives of Italian and Spanish ski resorts on their evaluation of the current situation of the ski resort and the importance that they attached to it with respect to the different dimensions of marketing. Moreover, the social media behavior on Facebook and Twitter of the ski resorts from those two countries was analyzed (through 15 and 11 indicators, respectively) and their behavioral patterns were profiled.

\section{Skiing Sports Tourism}

Together with the increase in economic activity related to sports, there is greater interest in the study of sports management [23] as a service provider that must concern itself with customer satisfaction, by implementing a specific results-oriented business style and culture [24].

Falk [25] affirmed that the demand for winter tourism depends on national and international income, prices, transport, costs, the location of the destination, and climate change. Climate change is 
fast becoming a significant factor [26] above all for low-altitude ski resorts in southern countries [27-29]. On the one hand, demand is considerably weaker when the depth and the quality of the snow is poor [25]; hence the business investments in, above all, high-altitude ski resorts [30]. On the other hand, new competitors from Eastern Europe and Asia offering new infrastructure and competitive pricing affect ski resorts in western-European countries. In addition, the tendency of mountainous regions is observed to evolve from mass tourism to multi-niche tourism [19].

Both internal aspects (i.e., characteristics of the individual and personal motives) and external aspects (characteristics of the destination) intervene in the choice of a ski resort, according to Pearce and Schänzel (2013). The motives of the traveler and the perceived capacity of a resort to satisfy previous expectations are variable strategies in the marketing of destinations [17]. Consequently, destination marketing and the promotion given to the activities which take place at the ski resorts become a key attractor for tourists when choosing destinations.

Winter sports tourism takes place in a natural environment that, because of its characteristics, requires high levels of investment in infrastructure and maintenance [6]. Resorts should also have a strategy that considers sustainable forms of development that are both competitive and profitable [31]. These destinations have to listen to what the visitor says and be concerned with the long-term sustainability of their surrounding environments [21,32].

The problem of seasonality and variability may also be added, given that the duration of the season depends on climatic conditions. One way of mitigating the effects of seasonality is by offering complementary alternative activities, whether sports-related (walking and mountain biking), cultural, or gastronomic. Complementary offers may also be developed for the non-skier market (relaxation, restaurants, après ski activities, etc.) [7], as well as even for amateur photographers, and areas for playing in the snow [33].

Ski resorts in both Spain and Italy have been selected for this study. In Spain, there are $30 \mathrm{ski}$ and mountain resorts affiliated to Asociación Turística de Estaciones de Esquí y Montaña, (ATUDEM) [34], a business association created in 1974. The ski resort sector moves over 5 million visitors, the great majority of whom are sports men and women, and has a turnover in excess of 115 million Euros [35]. In Italy, there are 293 ski resorts where the importance of skiing makes it a good reference for Spanish resorts. According to the Study Centre of the Confederazione Nazionale dell'Artigianato e della Piccola e Media Impresa (CNA) [36], the 2017 season yielded an income of some 10.6 thousand million Euros. If we count hotels, direct services to tourism activities, and other hotel and catering-related services, the number of visitors with respect to the previous season increased by $6.2 \%$, reaching almost 11 million tourists.

\subsection{Ski Resorts: Management Policies and Marketing}

Studies predominate in the academic literature on the investigation of marketing at ski resorts that take the perspective of skier into consideration, particularly the interest of the skier in the principal attributes that a high-quality ski resort should have and their evaluation. A quantitative type of methodology has been adopted in the majority of investigations, when analyzing the satisfaction and quality of ski resorts from a marketing perspective (see Table 1).

The satisfaction of skiers depends on the fun factor, the transport, the employees, and the lodgings [1]; ski-lifts, slopes quality, restaurants, equipment, and employees [5]; installations and equipment, features of the mountains, resort services, restaurants, lodging and social activities, and access [11].

Kyle et al. [37] demonstrated the positive effect of satisfaction on the loyalty of skiers. Kaplanidou et al. [38] affirmed that the organization of sporting events is a variable that influences future loyalty and attachment towards a destination, while "word of mouth" over social media positively influenced the destination image, the attitudes, and the intentions of tourists to make and to repeat a visit [39]. 
Table 1. Studies on the analysis of ski tourism and motives for the choice of ski resorts.

\begin{tabular}{|c|c|c|c|}
\hline Authors/Year & Country & Data Analysis & Conclusions \\
\hline Richards (1996) [44] & United Kingdom & $\begin{array}{l}\text { Descriptive statistics and } \\
\text { bivariable analysis }\end{array}$ & $\begin{array}{l}\text { The advanced/expert skiers are more critical of the quality } \\
\text { of ski-resort installations but pass more time at the } \\
\text { destination and use the resources with greater frequency. } \\
\text { The most important factor is snow quality. }\end{array}$ \\
\hline Hudson and Shephard (1998) [42] & Switzerland & $\begin{array}{l}\text { Focus group, in-depth } \\
\text { interviews, and IPA. }\end{array}$ & $\begin{array}{l}\text { IPA provides a useful technique with which to evaluate } \\
\text { the attributes of the service in relation with ski resort } \\
\text { destinations. The authors identified } 12 \text { factors for the } \\
\text { evaluation of the services of tourism resort: Information } \\
\text { services, lodging; restaurants and bars at resorts; ski shops } \\
\text { and medical services; shops and supermarkets; other } \\
\text { resort services; ski slopes; on-slope services; characteristics } \\
\text { of other skiers; mountain restaurants outside tourism } \\
\text { centers, and tourism operator services. }\end{array}$ \\
\hline Matzler and Siller (2003) [17] & Germany & $\begin{array}{l}\text { Descriptive analysis and } \\
\text { regression. } \\
\text { Importance-perception } \\
\text { matrix. }\end{array}$ & $\begin{array}{l}\text { Winter tourists expressed greater satisfaction with the } \\
\text { resorts than summer tourists did. In addition, the } \\
\text { motivations of both are different, as the skiers take sport } \\
\text { and fun into account more than any other variables. }\end{array}$ \\
\hline Clark and Maher (2007) [18] & United States & Logistic regression & $\begin{array}{l}\text { Trust, commitment, satisfaction, previous experience, } \\
\text { and perceived value predicted the loyalty of the skier. }\end{array}$ \\
\hline Dickson and Faulks (2007) [16] & Australia & Content analysis & $\begin{array}{c}\text { The people that indicated their intention of travelling } \\
\text { abroad to practice snow sports were, in their majority, men } \\
\text { with experience of snow sports, under } 35 \text { years old, with } \\
\text { a high educational level and income. }\end{array}$ \\
\hline Matzler et al. (2008) [5] & $\begin{array}{l}\text { Austria, Germany, Italy, } \\
\text { and Switzerland }\end{array}$ & Structural equations & $\begin{array}{l}\text { The components of satisfaction were ski lifts, slopes } \\
\text { quality, offer of restaurants, equipment, and employees. } \\
\text { Age, sex, slopes difficulty at the resort, and (new or } \\
\text { repeating) visits were all moderators of satisfaction. }\end{array}$ \\
\hline Hwa-Ryong and Sung-Kyeom (2010) [43] & South Korea & IPA & $\begin{array}{l}\text { The most important elements according to the matrix were } \\
\text { proximity of resort, skiing courses, availability of skiing } \\
\text { courses and type of ski lifts, tourism offer, lodging, skiing } \\
\text { and snowboard programs, and snow conditions. }\end{array}$ \\
\hline Vassiliadis, Priporas and Andronikidis (2013) [45] & Greece & $\begin{array}{l}\text { Time-Blocking Activity } \\
\text { Matrix (TBAM) }\end{array}$ & $\begin{array}{l}\text { The TBAM is proposed as a strategic tool to structure } \\
\text { decision-making in the management of tourism. } \\
\text { Expenditure patterns in relation to specific blocks of time } \\
\text { related to preferential products and services and } \\
\text { their consumption. }\end{array}$ \\
\hline Tjørve, Lien, and Flognfeldt (2015) [3] & Norway & Regressions & $\begin{array}{l}\text { Ski resorts have no clear and defined marketing strategy. } \\
\text { Foreign skiing tourists are not very interested in other } \\
\text { snow-based activities or cultural attractions. }\end{array}$ \\
\hline Komppula and Laukkanen (2016) [46] & Finland & $\begin{array}{l}\text { Content analysis and } \\
\text { analysis of variance } \\
\text { (ANOVA) }\end{array}$ & $\begin{array}{l}\text { Four differentiating factors were found for resort image: } \\
\text { Alpine skiing services, cross-country skiing services, } \\
\text { restaurants and social life, and spa services. }\end{array}$ \\
\hline Miragaia, Conde and Soares (2016) [11] & Portugal & $\begin{array}{l}\text { Cluster and factor } \\
\text { analysis and ANOVA }\end{array}$ & $\begin{array}{l}\text { Five factors affect satisfaction: Installations and } \\
\text { equipment; features of the mountains; resort services; } \\
\text { restaurants, lodging and social activities; and access. No } \\
\text { gender differences were observed, but differences were } \\
\text { noted between the experience and motivation of the skier. }\end{array}$ \\
\hline Hall, O'Mahony and Gayler (2017) [1] & Australia & $\begin{array}{l}\text { Cluster analysis and } \\
\text { structural equations }\end{array}$ & $\begin{array}{l}\text { Fun factor, transport, employees, and lodging were the } \\
\text { most important factors. }\end{array}$ \\
\hline
\end{tabular}

The choice of ski resorts is subject to the conditions of the snow and the variety of slopes [16], or in the case of ski and snowboard tourists, safety and snow quality, the variety of slopes, and the off-piste areas [31]. Different studies have centered on defining both the demographic and the psychographic profiles of the skiers $[31,40]$.

However, few studies have analyzed the opinions of other agents within the resorts, such as directors, employees, and marketing professionals. Ismert and Petrick [41] analyzed the organizational culture of the resorts, concluding that the employees valued socialization (relations with companions, and performance and treatment of the directors) as the most important aspects for the proper functioning of the firm. Tjørve, Lien and Flognfeldt [3] found that the marketing policies had little impact among skiers. 
Hudson and Shephard [42] and Hwa-Ryong and Sung-Kyeom [43] analyzed ski resorts through the importance-performance analysis (IPA). The skiers attached greater importance to information services, lodging, ski shops, medical services, shops and supermarkets, ski slopes, ski-slope services, tourism services operators, proximity of the resort, and types of ski-lifts. Matzler and Siller [17] applied a variation known as the importance-perception matrix through which the principal motivations of the skiers are established.

\subsection{Skiing Stations and Use of Social Networks}

The use of the Internet and virtual social media for the development of relations with clients and users of firms has intensified over recent years [47], assuming a high profile, because they generate real-time communication, cooperation, and geographical proximity [48]. Two social media networks with the highest number of users, among both firms and individuals, are Facebook and Twitter [49].

Chen [50] demonstrated that the use of Twitter permits users to feel continually connected and informed, while Zhang et al. [51] affirmed that the use of Facebook offers emotional support, collective self-esteem, and amusement. Facebook is a platform that offers different tools to firms, so that they are able to publicize their activities with actual and potential audiences, for which reason it plays a very important role in marketing policies [52,53].

The literature highlights the role of the 'brand' community of a firm as a powerful influence on the strength of the relations between the participants of the community and the firm [54]. The interaction between members can help the followers of a brand to feel that they are active participants rather than mere spectators or visitors to their installations [55].

The benefits of the use of social media have been demonstrated within the area of sports marketing. Baena [56] showed that the traditional websites of football teams are no longer sufficient, because the interactive medium of a social media site favors choice and commitment towards the brand or the firm. Ioakimidis [57], in an analysis of the accounts of professional sportspersons, showed improvements in the relations with their followers. A website is an effective means for the marketing of organizations that, if well-constructed (home page, content, use of advertisements, etc.), will help to form ties of loyalty with the visitors [58-60].

There are few studies that have analyzed the role and the results of the use of social media among skiing resorts. Massa and Avesani [61] analyzed the Internet sites of skiing stations, to predict user preferences in terms of the trust-related metrics that the users expressed. Gretzel et al. [62] discussed the possibilities that the Internet can provide for the promotion of the various skiing destinations.

Other investigations detected weak exploitation of this instrument, revealing the need to reinforce resources and not to overlook the opportunities provided by the ICTs [6]. It has been confirmed that almost all ski resorts have their own websites, but a mere presence in the world of the Internet is not a factor that is, in itself, sufficient. It is necessary to create links with both consumers and users [21]. Social media networks contribute significant support to achieve such links [63]. Despite all of the above, no analysis has yet been completed on the use of social media and skiing resorts, nor are there studies of their impact on commitment towards clients and winning over new ones.

\section{IPA (Importance-Performance Analysis)}

The importance-performance analysis is a management tool that assumes a focus of expectations and performance to measure the perceptions of quality that has been widely used in the literature $[4,5,64,65]$. It is used to provide guidelines for strategic decision-making in marketing. In the case of the skiing stations, Hudson and Shephard [42] considered it a very useful tool and a decisive one for the planning of marketing. Hwa-Ryong and Sung-Kyeom [43] used it to analyze the attributes of the seasons from the viewpoints of the visitors.

This matrix is used to evaluate the different characteristics of an organization (perceptions of performance and the importance of results), so as to establish the strong points and the areas for the improvement of an organization (perceptions of performance and importance of the results), 
when comparing the importance that is given to each attribute with the assessment or performance that is attributed to it. It has been used in different areas such as universities $[66,67]$ and strategic city planning [68].

In this investigation, it is the directors and representatives of the ski stations who have to assess the importance and the performance of their resorts against the different aspects of the dimensions of applied marketing, on the basis of the proposal of Kotler and Dubois [20]. The authors identified six dimensions relating to the surrounding environment, strategy, organization, system, productivity, and functions.

\section{Methodology}

\subsection{Survey for the Application of the IPA}

The IPA matrix is a basic diagnostic decision tool [4] that facilitates the identification of the prioritization of improvements, the mobilization and deployment of scarce resources where they are most needed [69], and the harmonization of strategic planning efforts to improve competitiveness [70]. In the tourism sector, IPA is considered a useful tool to examine customer satisfaction and management strategies. This technique can help tourist companies to diagnose the underlying deficiencies and establish priorities in the development of their activity [71].

There are many studies about theoretical and practical aspects of IPA that inform about how to solve the key decisions: Use data-centered, scale-centered, and diagonal methods; how to interpret the quadrants or choose the thresholds or the cross-hair points; how to measure importance (direct or indirect); how to validate [70-73].

In the application of the IPA matrix, the recommendations of the literature have been taken into account [70-74]. These recommendations have been considered in both the process and conceptual issues: Definition of importance, distinguished in the same quadrant, determination of a reference criterion [71]. In summary, the process consists of the following steps:

- Define the problem or challenge: Perform an internal marketing audit in the ski resort sector;

- Specify the objective: From the practical and management point of view, know the strengths, weaknesses, and deficits in the application of marketing in the ski sector, following the analysis of the IPA quadrants. From the methodological point of view, the purpose is to try a new form of validation: The application of the ROC curve (receiver operating characteristic);

- Selection of items: The appropriate items had to be selected that covered the best possible application of marketing to skiing resorts. Based on the proposal of Kotler and Dubois [20], 83 items were prepared and grouped into the six aforementioned dimensions. The items were assessed by four marketing experts in the framework of the Delphi model. After the first assessment, each expert had access to the average score of each item (on a scale from 1, of little importance, to 10, very important), before moving on to the second vote. The items with the highest average scores for importance and the lowest standard deviation were selected. Finally, the questionnaire was formed of 32 items of the six aforementioned dimensions, which are listed in Appendix A. Unlike previous literature focused on the evaluation of tourists (skiers) $[45,73]$ where consumer satisfaction was assessed through the IPA matrix, we analyze the adequacy of marketing management from the point of view of managers. Therefore, it is expected that all the items result to be very important and the difference is the self-perceived deficit in the marketing application;

- Measure: It was carried out obtaining direct data. All items were measured on a Likert scale from 0 to 10 points. In order to do this, the indications of Alpert [75] and Bacon [72] were followed. In according to these authors, direct measurements better reflect the attribute than indirect methods. Direct gradings are more stable and valid, and better reflect the importance of the attribute compared to indirect measures [70,76];

- Validation: Through the application of the ROC curve, according to Server [71], it could provide the criteria for an optimal categorization of the elements in the framework of IPA. 
The objective population (universe) were all Spanish and Italian ski resorts. All the Spanish Alpine ski resorts, of which there are 30, were contacted via email; Although 293 Italian resorts were identified, in many cases, they formed part of the same district, so altogether, a total of 122 surveys were sent out.

The Qualtrics platform was used for the (self-administered) application and management of the questionnaire, sending out a hyperlink to the directors and technicians for the questionnaire to be completed online. Various surveys were sent out during the months of November and December 2017, and January 2018. In total, 29 responses were obtained, of which 8 were from Italian resorts.

The analysis of the items of the IPA matrix was done by applying non-parametric tests (Wilcoxon's test, Mann-Whitney test) for the separate items; thereby confirming whether there were significant differences between the importance and the performance attributed to each one.

Table 2 shows the main descriptive data about ski resorts in Spain and Italy. Italians are bigger, receive more visitors, and have more kilometers of skiing on average.

Table 2. Descriptive data of ski resorts.

\begin{tabular}{ccccc}
\hline & \multicolumn{2}{c}{ Spain } & \multicolumn{2}{c}{ Italy } \\
\cline { 2 - 5 } & Mean & Stand.Desv. & Mean & Stand.Desv. \\
\hline Opening days & 83.97 & 55.06 & 131.85 & 20.803 \\
Total visitors & 193,861 & 282,090 & n.d. & n.d. \\
Turnover & $5,019,110$ & $7,682,282$ & $22,355,240$ & $20,983,441$ \\
Kilometers of ski slopes & 40.26 & 39.24 & 103.7 & 87.29 \\
\hline
\end{tabular}

\subsection{Study of Social Networks}

It was decided to consider all the Spanish ski resorts and to choose the 20 most important Italian resorts by numbers of visitors, touristic importance, and prestige of the destination where the ski resort was found.

Two pages were used in the analysis of the social media that offered free data relating to position, activity, relevance, etc. that the ski resorts obtained on their respective Facebook and Twitter pages. The indicators are shown in Tables 5 and 6 . The pages were LikeAlyzer for Facebook and Foller for Twitter, both consulted during the month of November 2017.

Non-parametric tests and cluster analysis were used in the analysis of the social media data. All analyses were done with the Statistical Package for the Social Sciences (SPSS) 20 software package.

\section{Results}

\subsection{Marketing Audit}

Appendix A contains the scores given by the directors of the ski resorts to both importance and performance, and the differences (or deficit) between importance and performance of each of the 32 items used to conduct the audit, which are shown in Figure 1. In the last column, the significance level is shown of the difference between importance and performance. 


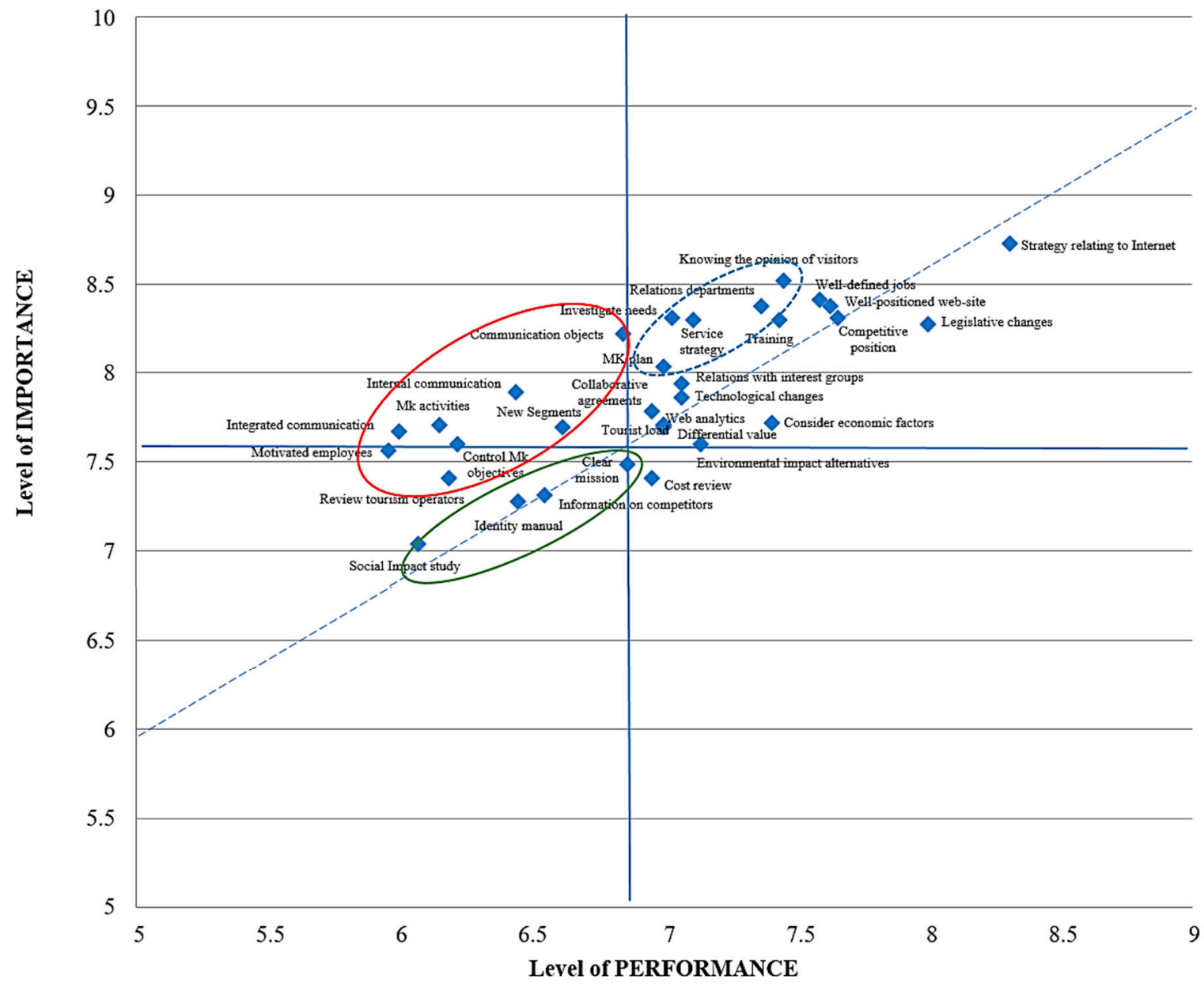

Figure 1. Importance-performance matrix.

First of all, according to the importance given by managers, a third of the characteristics considered most important-with scores of 8.22 to 8.72 over 10 and an average score of 8.87 (Appendix A)-are related to the analysis of the environment (to know the opinion of their visitors, to investigate the needs of the target public, and to respond to legislative change), the marketing strategy (the Internet forms part of the strategy, and the competitive stance of the resort is known, as are its threats and opportunities on which basis it defines its objectives and goals), the organization of the marketing (defining the jobs with objectives, responsibilities and sufficient authority; existence of good relations and communications between the marketing department and the others; and the training of those involved in marketing) and the functions (availability of a well-positioned website in the search engines; clear definitions of its service quality and its communications strategy both online and offline).

With regard to the items that were given less importance, the lowest scores were for productivity, strategy, functions, and marketing environment: Periodically studying the social impact that its services provoked between the communities based around the ski resort; follow-up of actions; availability of a manual of corporate identity; availability of information on objectives, strategies, strengths, and weaknesses of other resorts; looking for sustainable alternatives; controlling objectives; motivating employees, and periodic reviews of the cost of activities so that suitable measures may be taken.

Secondly, with respect to adequacy and according to the directors, one third of the items that presented better performance, in other words, what was done best (scores between 8.81 to 7.11 out of 10, where the highest average score of the top third was 7.56) was related to: 
- Environment: Considering the main economic events, looking for sustainable alternatives, knowing the opinions of visitors, and knowing and responding rapidly to legislative changes;

- Strategy: The Internet forms part of the marketing strategy of the station; knowing the competitive position, threats, and opportunities;

- Organization: Defining the jobs well, with objectives, responsibilities, and sufficient authority, existence of good relations between the marketing department and the others; and ensuring that those participating in the marketing activities are properly trained in their roles:

- Functions: Availability of a website that is well positioned among the search engines; and having clearly defined their service quality strategy.

On the contrary, the following items in the one third of characteristics with the worst performance or main weaknesses, with scores below 6.5 out of 10 and with an average score for the lower third of 6.32, may be highlighted as follows:

- Marketing functions: Communication adapted to the concept of integrated marketing; controlling the achievement of marketing objectives (offline and online); availability of an internal communications system; performing direct marketing activities, online, and in databases; periodic reviews of the efficiency of tourism operators;

- Organization: Employees who are motivated to achieve marketing objectives;

- Strategy: Availability of a corporate identity manual;

- Productivity: Periodically studying the social impact occasioned by resort services.

The scores for importance were always higher than for performance, with statistically significant (or quasi-significant) differences, with some exceptions (see Appendix A). Those exceptions were the situations in which it may be considered that no deficits existed; in other words, the consideration of performance was practically at the same level as that of importance. This balance is the case of six items relating to strategy, environment, functions, and productivity (Appendix A): Taking into account the principal economic events in their environment to take action; looking for sustainable alternatives relating to environmental impact; knowing and responding rapidly to legislative changes; the mission is clearly expressed, is feasible, and known by all members of the organization; periodic reviews of marketing activities; the services present some added value that differentiates them from other resorts.

The difference between importance and performance yielded a measure of the deficits existing in the management of marketing. The items of the dimensions of the environment and of marketing organizations predominate both importance and performance in the one-third with the highest scores. The contrary happens for the other dimensions, in particular for the systems and productivity. Table 3 shows the number of the items for the six dimensions (environment, strategy, system, productivity, functions) that are among the upper third of scores of importance $(+)$, in the central third (=), and in the lower third (-); and the same was done for performance and for the difference between importance and performance. When distinguishing between importance and performance, slight differences were found in the items of the dimensions for both environment and strategy. The greatest deficits, however, were found in the dimensions of the functions. In concrete, those deficits were:

- Functions: Adopt the concept of integrated marketing communication; conduct direct marketing activities, online, and with databases; availability of a system of internal communication; defining the communication objectives (on and offline); review the efficiency of the tourism operators and the internal communications system; clearly defining the quality strategy of its services;

- Environment: Annually investigate the needs of their objective public, gather the opinions of their (real and potential) visitors;

- Strategy: Look for new segments still unsatisfied or niche markets;

- Organization: Motivate employees to achieve (the weakest) marketing objectives; 
- Systems: Control the achievement of marketing objectives (offline and online).

Table 3. Distribution of the items of each dimension that are in the one-third with the highest $(+)$, the intermediate $(=)$, and the lowest $(-)$ blocks.

\begin{tabular}{|c|c|c|c|c|c|c|c|c|c|c|}
\hline \multirow{2}{*}{ Blocks } & \multirow{2}{*}{ Num. Items } & \multicolumn{3}{|c|}{ Importance } & \multicolumn{3}{|c|}{ Performance } & \multicolumn{3}{|c|}{ Differences } \\
\hline & & + & $=$ & - & + & $=$ & - & + & $=$ & - \\
\hline Environment & 7 & 3 & 2 & 2 & 4 & 2 & 1 & 2 & 2 & 3 \\
\hline Strategy & 8 & 2 & 3 & 3 & 2 & 4 & 2 & 1 & 3 & 4 \\
\hline Organization & 4 & 3 & & 1 & 3 & & 1 & 1 & 3 & \\
\hline System & 2 & & 1 & 1 & & 1 & 1 & 1 & & 1 \\
\hline Productivity & 3 & & 1 & 2 & & 2 & 1 & & 2 & 1 \\
\hline Functions & 8 & 3 & 3 & 2 & 2 & 1 & 5 & 6 & & 2 \\
\hline Total & 32 & 11 & 10 & 11 & 11 & 10 & 11 & 11 & 10 & 11 \\
\hline
\end{tabular}

After describing the results referring to importance, adequacy, and deficits, the IPA matrix has been carried out. The process is the one detailed below, following the criteria recommended in the previous literature on the application of IPA in the tourism sector [71,73,74]:

- The average values of performance, importance, and their difference are calculated. The difference is a measure of the self-perceived deficit in the application of marketing management to the ski resorts;

- When it comes to applying the IPA to consumer satisfaction, according to the theory of disconfirmation, if the performance-importance difference is zero or positive there is satisfaction, while there will be dissatisfaction if it is negative. In the current case, a zero or a positive difference is considered a sufficient application of marketing management, while if it is negative, it will be a poor application;

- The performance-importance thresholds (or crossing point) are identified to delimit the quadrants and to identify which items are in each one. To do this, we calculate the probability (sensitivity) that a great difference between performance-importance (a great deficit) is considered as a weakness or insufficient application of that characteristic. The probability (specificity) that a small difference is not considered a weakness is also obtained; in other words, a sufficient application is considered. The ROC curve offers information for all combinations of sensitivity and specificity. The closer you are to the diagonal, the less suitable the combination is; the farther you go, the more appropriate;

- Validation by measuring the power of discrimination of the ROC curve and the Youden test [77]. The power of discrimination of the ROC curve is the area under the ROC curve (AUC); in other words, the probability that the value of the diagnosis is greater than that randomly selected with a positive result rather than with a negative result. The value of 0.5 means that accuracy is equal to a random chance, while the value of 1 means higher accuracy. In our case, the performance has an AUC value of $0.79(0.00)$, which is fair. According to importance, the discriminatory power is poor (0.51): Managers do not discriminate a lot in terms of the importance of the selected items. Youden's test provides a measurement of importance considering sensitivity and specificity for every point of the ROC curve. Youden's test is equal to sensitivity plus specificity minus 1 . The point to choose is the higher one. Table 4 shows how to obtain the values of Youden's test for performance. The highest value for performance of the Youden's test is 6.85. Doing the same for importance, it obtains the highest value for importance in this test at 7.69. These values do not differ much from the average values for performance (6.96) and importance (7.88).

- Representation (Figure 1). The discriminating thresholds are the highest values of performance and importance for the test of Youden. These values are used to identify the cut-off. In the analysis of the resulting quadrants of the IPA matrix, it is possible to check those aspects that are carried out properly in the sector of the ski resorts, as well as those with notable deficiencies. 
Table 4. Youden's test for performance.

\begin{tabular}{cccc}
\hline Positive if Less than or Equal to & Sensitivity & 1-Specificity & Youden's Test \\
\hline 4.96 & 0.00 & 0.00 & 0.00 \\
5.98 & 0.07 & 0.00 & 0.07 \\
6.03 & 0.14 & 0.00 & 0.14 \\
6.11 & 0.21 & 0.00 & 0.21 \\
6.17 & 0.29 & 0.00 & 0.29 \\
6.205 & 0.36 & 0.00 & 0.36 \\
6.33 & 0.43 & 0.00 & 0.43 \\
6.44 & 0.50 & 0.00 & 0.50 \\
6.5 & 0.50 & 0.06 & 0.44 \\
6.58 & 0.50 & 0.11 & 0.39 \\
6.73 & 0.57 & 0.11 & 0.46 \\
6.85 & 0.64 & 0.11 & 0.53 \\
6.91 & 0.64 & 0.17 & 0.48 \\
6.98 & 0.64 & 0.28 & 0.37 \\
7.01 & 0.71 & 0.44 & 0.27 \\
7.05 & 0.79 & 0.44 & 0.34 \\
7.09 & 0.79 & 0.23 \\
7.12 & 0.76 & 0.30 \\
7.25 & 0.86 & 0.56 & 0.25 \\
7.39 & 0.86 & 0.61 & 0.32 \\
7.42 & 0.93 & 0.61 & 0.26 \\
7.52 & 0.93 & 0.67 & 0.21 \\
7.61 & 0.93 & 0.72 & 0.28 \\
7.64 & 1.00 & 0.72 & 0.22 \\
7.83 & 1.00 & 0.78 & 0.17 \\
8.15 & 1.00 & 0.83 & 0.11 \\
9.31 & 1.00 & 0.89 & 0.06 \\
& 1.00 & 0.94 & 0.00 \\
\hline & 1.00 & 1.00 & \\
\hline & & & \\
\hline & & & \\
\hline & & & \\
\hline
\end{tabular}

Five aspects are performed especially well in the sector (those items belonging to the blue circle): availability of a coherent and feasible marketing plan; clearly defined service quality strategy; annual investigation of the public target's needs of the ski resort; existence of good relations and communications between the marketing department and the other departments; and the ski resort knows the opinion of its (real and potential) visitors. What the ski resorts do best is related to the environment, although aspects related to sustainability do not stand out. It highlights the fact that no aspects related to the dimensions of marketing systems and productivity are among the best.

By contrast, the aspects of marketing with the most deficient application in the ski resorts are: Employees are motivated to achieve the marketing objectives; communications are adapted to the concept of integrated marketing communication; ski resort has a system of internal communication; ski resort performs direct marketing, online marketing, and database marketing activities; ski resort defines and is clear with regards to its online and offline communications objectives (publicity and promotion); and the ski resort looks for new unsatisfied segments and market niches. Therefore, the biggest deficiencies are related to the dimension of marketing functions.

The matrix also helps to detect those aspects to which the sector grants a lower priority (green circle). They are the following: Ski resort periodically studies the social impact of its services; availability of a manual on corporate identity; the mission is clearly expressed, is feasible, and known to all members of the organization; and the ski resort knows its competitive position and its threats and opportunities, in order to define objectives. In this case, they are the elements (three of them) related to the strategy dimension.

Therefore, it can be concluded that those that perform best relate to the environment, while the greatest deficiencies are found in the functions. That which is not paid special attention or priority is related to the marketing strategy.

Finally, analyzing the differences between Italy and Spain, there is a high coincidence when evaluating the items of both performance and importance among the managers of the ski resorts from the two countries. Only the Mann-Whitney test uncovered differences with regards to performance in availability of corporate identity manual and use of web analytics tools, with higher scores in Spain in 
both cases. The Italians related better performance with a marketing strategy that took into account the proper tourist load for the ski resort.

With regards to the scores for importance, the strategy of promoting good relations with stakeholder groups was scored more highly in Spain.

\subsection{Social Network Analysis}

The first point that was confirmed in the analysis of behavioral patterns on social media was in regard to Twitter, with which all the resorts that were selected have an account. There were no significative differences between both countries in the majority of indicators on Twitter (Table 5). It was notable that the ski resorts in Spain surpassed those of Italy in terms of tweets, followers, following, followers per following, replies, listed, and tweets with links. The opposite was true for tweets with mentions, tweets with hashtags, retweets, and tweets with media. However, significant differences only occurred with tweets and followers and listed, which were always greater in Spain.

Table 5. Average values of indicators on Twitter for the Spanish and the Italian ski resorts.

\begin{tabular}{ccccc}
\hline Indicator & Description & Spain & Italy & Significance Level \\
\hline Tweets & Number of tweets & 3865.85 & 3363.53 & 0.022 \\
Followers & Number of followers & 6929.32 & 4464.80 & 0.050 \\
Following & Number of followed & 275.21 & 265.27 & Insig. \\
Followers per following & Followers per following & 28.37 & 4.88 & Insig. \\
Listed & Number of searches via lists & 109.50 & 67.07 & 0.050 \\
Replies & Number of responses over 100 & 5.29 & 4.93 & Insig. \\
Tweets with @mentions & Tweets with mentions over 100 & 32.71 & 51.00 & Insig. \\
Tweets with \#hashtags & Tweets with hashtags over 100 & 37.26 & 57.00 & Insig. \\
Retweets & Number of retweets over 100 & 18.94 & 32.67 & Insig. \\
Tweets with links & Tweets with links over 100 & 64.62 & 56.60 & Insig. \\
Tweets with media & Tweets with multimedia over 100 & 19.00 & 26.80 & Insig. \\
\hline
\end{tabular}

Source: Foller. Significance level for the Mann-Whitney U test of differences.

With regarda to Facebook, the Italian ski resorts were much more dynamic in relation to practically all the indicators, with two exceptions: Notes and average post length (Table 6). There were statistically significative differences (in the Mann-Whitney test) for about, response, total Page likes, and native Facebook videos, with greater activity at the Italian ski resorts in all cases.

Table 6. Average values of indicators on Facebook for the Spanish and the Italian ski resorts.

\begin{tabular}{|c|c|c|c|c|}
\hline Indicator & Description & Spain & Italy & Significance Level \\
\hline Frontpage & Visits to Frontpage & 0.917 & 0.981 & Insig. \\
\hline About & Additional information & 0.770 & 0.831 & 0.07 \\
\hline Activity & Percentage activity of the page & 0.538 & 0.697 & Insig. \\
\hline Response & Number of responses & 0.384 & 0.475 & 0.08 \\
\hline Photos & Percentage of photographs & 0.546 & 0.728 & Insig. \\
\hline Videos & Percentage of notes & 0.218 & 0.122 & Insig. \\
\hline Notes & Percentage of videos & 0.114 & 0.160 & Insig. \\
\hline People talking about this & People posting comments on the page & 782.50 & 3100.35 & Insig. \\
\hline Total Page likes & Total "likes" received & $22,434.72$ & $40,797.90$ & 0.048 \\
\hline Engagement rate & Implication & 0.026 & 0.502 & Insig. \\
\hline Posts per day & Daily posts & 0.361 & 1.485 & Insig. \\
\hline Average post length & Average length of post & 226.97 & 206.2 & Insig. \\
\hline Events & Events created & 1.39 & 5.95 & Insig. \\
\hline Pages liked & Number of likes received & 33.92 & 52.45 & Insig. \\
\hline Facebook native videos & Videos posted on the page & 5.25 & 9.4 & 0.07 \\
\hline
\end{tabular}

Source: LikeAlyzer. Significance level for the Mann-Whitney U test of differences.

In Tables 7 and 8, the results of the Pearson's correlation analysis between the indicators of social networks and the main descriptive indicators of the ski resorts (opening days, total visitors, kilometers of ski slopes, and turnover) are shown. With regard to Twitter, there is a positive correlation in several cases. Open days correlate with number of tweets, listed, tweets with mentions, and tweets with hashtags. Open days denote more activity but links, multimedia, or more followers do not. 
The total number of visitors to the ski resorts is correlated with tweets, followers, following (incorporates social mass), listed, and tweets with hashtags. Kilometers of slopes do not provide new information to the previous results. It is correlated with tweets and tweets with hashtags. Finally, the turnover only correlates with the number of following.

Table 7. Correlation between Twitter indicators and descriptive data of ski resorts.

\begin{tabular}{ccccc}
\hline & Opening Days & Total Visitors & Kilometers of Ski Slopes & Turnover \\
\hline Number of tweets & $0.41^{* *}$ & $0.64^{* *}$ & $0.41^{*}$ & 0.18 \\
Followers & 0.24 & $0.83^{* *}$ & 0.18 & 0.21 \\
Following & 0.25 & $0.39^{*}$ & 0.23 & $0.49^{* *}$ \\
Followers per following & -0.12 & 0.02 & -0.17 & -0.17 \\
Listed & $0.31^{*}$ & $0.87^{* *}$ & 0.21 & 0.22 \\
Number of responses over 100 & 0.22 & 0.38 & 0.20 & -0.01 \\
Tweets with mentions over 100 & $0.37^{*}$ & 0.08 & 0.27 & 0.23 \\
Tweets with hashtags over 100 & $0.577^{* *}$ & $0.56^{* *}$ & 0.13 & 0.27 \\
Number of retweets over 100 & 0.24 & -0.04 & -0.11 & 0.27 \\
Tweets with links over 100 & 0.13 & 0.08 & 0.15 & -0.08 \\
Tweets with multimedia over 100 & -0.11 & 0.11 & 0.18 \\
\hline
\end{tabular}

** Significance level of 0.01 . * Significance level of 0.05 .

Table 8. Correlation between Facebook indicators and descriptive data of ski resorts.

\begin{tabular}{|c|c|c|c|c|}
\hline & Opening Days & Total Visitors & Kilometers of Ski Slopes & Turnover \\
\hline Frontpage & 0.18 & 0.19 & 0.25 & 0.23 \\
\hline Additional information & 0.15 & 0.13 & 0.16 & 0.27 \\
\hline Percentage activity of the page & $0.38^{* *}$ & $0.45 *$ & $0.32 *$ & 0.34 * \\
\hline Percentage of photographs & 0.02 & -0.02 & 0.11 & $0.31 *$ \\
\hline Percentage of notes & -0.07 & 0.02 & -0.09 & -0.24 \\
\hline Percentage of videos & $0.29 *$ & 0.24 & 0.17 & -0.04 \\
\hline Total "likes" received & 0.27 & $0.87^{* *}$ & $0.69 * *$ & $0.48^{* *}$ \\
\hline Implication-engagement rate & 0.15 & 0.32 & -0.06 & -0.02 \\
\hline Daily posts & $0.29 *$ & 0.17 & $0.40 * *$ & 0.24 \\
\hline Average length of post & -0.05 & 0.10 & 0.05 & 0.01 \\
\hline Events created & 0.26 & $0.80 * *$ & $0.50 * *$ & $0.61 * *$ \\
\hline Number of likes received & 0.24 & $0.61 * *$ & $0.42 * *$ & $0.30 *$ \\
\hline
\end{tabular}

** Significance level of 0.01 . Significance level of 0.05 .

With regards to Facebook, it is interesting that three indicators (activity, people posting comments on the page, and total page likes) are correlated with the four indicators of ski resorts. Turnover has also a great number of correlations. Apart from the three mentioned, it has correlations with percentage of photographs and events created. Strong correlations occur with the descriptive indicator of open days. The activity on Facebook has more to do with the volume and business characteristics of the ski resorts than the Twitter indicators, in particular regarding turnover.

\subsection{Ski Resort Clusters by Twitter and Facebook Indicators}

The values related to the behavioral patterns of the ski resorts on the two social media networks were normalized, to identify clusters of ski resorts. After applying different procedures of hierarchical grouping, such as the Ward and the complete linkage method, with different distance factors, it was concluded that the most appropriate grouping was the one formed by four groups. Having decided on the number of groups, the k-means cluster analysis option was performed, yielding the results that are commented on below (Table 9). 
Table 9. Clusters identified by indicators on Twitter and Facebook. Normalized values.

\begin{tabular}{|c|c|c|c|c|}
\hline Cluster & Average Profile & Inactive & Leader & Aversion to Twitter \\
\hline Tweets & 1.285 & -0.772 & 2.457 & -1.008 \\
\hline Followers & 0.178 & -0.498 & 6.188 & -0.449 \\
\hline Following & 2.289 & -0.775 & -0.846 & -0.360 \\
\hline Followers per following & -0.197 & 1.207 & 0.542 & -0.139 \\
\hline Listed & 0.543 & -0.931 & 4.048 & -0.942 \\
\hline Replies & -0.982 & -0.982 & 0.908 & -0.415 \\
\hline Tweets with mentions & -0.672 & -1.371 & -0.148 & -0.148 \\
\hline Tweets with hashtags & 0.506 & -1.275 & 0.902 & -0.167 \\
\hline Retweets & -0.355 & -0.964 & -0.395 & -0.395 \\
\hline Tweets with links & 0.894 & -0.366 & 0.440 & -0.114 \\
\hline Tweets with media & -0.281 & -1.207 & 0.210 & 1.245 \\
\hline Frontpage & 0.380 & -4.481 & 0.380 & 0.380 \\
\hline About & 0.931 & -4.216 & -0.437 & -0.437 \\
\hline Activity & 0.972 & -2.324 & 0.972 & -0.139 \\
\hline Response & 0.202 & -1.593 & -1.593 & 0.202 \\
\hline Photos & 0.381 & -2.198 & 0.344 & 0.492 \\
\hline Notes & -0.543 & -0.869 & -0.590 & -0.683 \\
\hline Videos & 0.134 & -1.186 & 1.014 & 0.486 \\
\hline People talking about this & 0.155 & -0.528 & 3.658 & 3.806 \\
\hline Total page likes & 1.456 & -0.804 & 2.990 & 0.325 \\
\hline Engagement rates & -0.161 & -0.188 & -0.106 & 0.111 \\
\hline Posts per day & 0.080 & -0.564 & -0.207 & 5.879 \\
\hline Average post length & 0.821 & -1.540 & -0.081 & -0.298 \\
\hline Events & 3.363 & -0.492 & 3.363 & -0.492 \\
\hline Pages liked & 1.418 & -1.069 & 1.418 & -0.770 \\
\hline Facebook native videos & 1.469 & -0.883 & 1.841 & 0.850 \\
\hline
\end{tabular}

Bold: Highest values between the different clusters. Italic: Lowest values between the different clusters. Shaded : No significant differences.

Cluster 1: Average profile on social media

This cluster was formed of ski resorts that are neither prominent, because of their activity either on Twitter or on Facebook, nor stand out, nor have the lowest level of activity on social media. They only stand out because of frontpage and about in Facebook. It comprises the great majority (34) of the ski resorts and represents an intermediary profile in the use of social networks.

Cluster 2: Inactive on social networks

This cluster has the fewest indicators on both social media networks. The ski resorts in it had the lowest values in 19 of the 26 indicators, only standing out because of the high number of followers per following on Twitter and notes on Facebook. The least active resorts on both Twitter and Facebook topped the list. This group was formed of eight ski resorts, of which the seven Spanish ones were the least active. Among those resorts, we may mention the following: Port Ainé, Valdezcaray, San Isidro, Astún, Navacerrada, La Pinilla, and Vigo di Fassa.

Cluster 3: Most active on social media networks

This cluster has the highest activity both on Twitter and on Facebook. It presented the highest indicators for both networks: On Twitter, it had the highest score for 6 of the 11 indicators. The single resort in this cluster had the most tweets, the most followers, the most searches via lists (referred to as listed), replies, and tweets with links, while its own accounts followed others less than any other to the Twitter accounts. It is the leading Twitter account in the universe under analysis and corresponds to the ski resort of Sierra Nevada. Something similar was found on Facebook, where it especially stands out on videos, people talking about this, total page likes, events, pages liked, and Facebook native videos.

Cluster 4: Aversion to Twitter 
These resorts show very little activity on Twitter but are moderately active on Facebook. They are the resorts with the fewest tweets, the fewest followers, and the fewest followers per following. Nevertheless, they head the list of tweets with mentions and retweets. The high number of responses, photos, posts per day, and average post length may note their greatest activity on Facebook. The other indicators of the cluster usually left it in second position. The Italian ski resorts that stood out in this cluster were as follows: Madonna di Campiglio and Monterosa Gressoney marked by their preference to use Facebook and their non-use of Twitter.

The most similar clusters were 1 and 4, while the most different clusters were 2 and 3.

We have analyzed the possible differences between the clusters in relation to the four descriptive indicators of the ski stations. The non-parametric Kruskal-Wallis test shows that there are only differences between the clusters for the variable "open days" $(p=0.02)$. Sierra Nevada is the ski station with the greatest number of opening days, and it stands out in the cluster "active in social media" (3). Opening days is the variable that makes the difference in the social networks' activity of the ski stations.

\section{Discussion}

Tourism is a very dynamic sector with strong growth. Sport represents an activity that is practiced in an increasingly significant manner. The segment of sports tourism is of great social and economic impact. Tourism linked to the practice of skiing involves some 80 countries with approximately 400 million annual visiting skiers [78].

The management of ski resorts has its peculiarities and, in particular, the marketing of ski resorts. The existing literature has centered on studies of motivations for the choice of resort and satisfaction with the experience of the visit. There are no studies on the assessments of ski-resort directors with regards to the performance and the importance of the marketing dimensions of their resorts.

A methodology based on the IPA with a list of items to conduct this type of marketing audit of ski stations has been used to analyze the responses of ski-resort directors, in both Spain and Italy, to the survey. From the results, the following may be deduced.

IPA is a widely used tool in the tourism sector, useful for evaluating the service of tourism companies [71,79] and, specifically, ski resorts [42,43].

Among the results, the importance of online management has been proven. The use of the Internet as a source of information and interaction with visitors was confirmed as a fundamental aspect to highlight among the tasks of ski-resorts [62]. The information that users can accumulate and/or consult on their mobile phones is larger and larger. In addition, technological development makes it possible to personalize the services that are on offer in accordance with the characteristics of the consumers and the collection of valuable information in the form of big data [80].

The above is connected with the need to be consumer oriented and to know your consumer, in order to differentiate the offer of the resort [14]. Well-defined positions of employment are important for successful marketing and, in agreement with [41], good relations with other departments. The attributes that stand out among the most important ones have to do with the surrounding environment, organization, and functions.

The lack of importance given to relations with members of its microenvironment (mainly, the operators) stands out. However, according to Zehrer and Hallmann [81], collaboration between the different stakeholders (community, suppliers, tourism operators, visitors, etc.) is decisive.

The literature on studies of social media at ski resorts is very limited. No references were found that identified typologies of behavior at the ski resorts with the detail that has been presented in this paper, through 11 indicators from Twitter and 15 from Facebook.

The recommendations at which we arrive from this study is the need to implement marketing planning from preparatory research (incorporating web analytics) up to implementation (in marketing activities, and specifically digital marketing actions, and the integration of communication actions) and, of course, follow up and control of objectives and costs. This planning should be sensitive and 
coordinated with impact studies on the ski resorts, reviewing and analyzing the tourist load, and the needs of their visitors. Communications with stakeholders should be meticulous with integrated and coordinated (online and offline) actions. Finally, another recommendation is to establish training and motivation plans for personnel that develop marketing activities, always from the perspective of ethical marketing and macro-marketing. In short, this study can serve to establish priorities and a working method for the improvement of the implementation of marketing at ski resorts.

In short, from the analysis, the direct implication for management is the need to improve the orientation toward a marketing application in a responsible manner in all its dimensions, from how a marketing strategy is formulated taking into account the environment, to how to involve the employees. It is necessary to implement actions aimed at finding the expectations of the stakeholders, including sustainable development and management to maintain the attractiveness of the stations.

The typologies of behavior on Twitter and Facebook provide the possibility of benchmarking for comparisons between the profiles or clusters and social media activity, especially to draw comparisons with the leading or most active ski resorts. One fundamental implication is to adopt an active behavior towards social media and with the followers, as there is a direct relation with the performance indicators of the resort.

As with all investigations, the present one also presents limitations. In the first place, the size of the sample for the marketing audit was reduced. Nevertheless, large sizes are not essential for this type of study consisting in positioning items, in order to arrive at an acceptable diagnosis. Moreover, only two social media networks and certain indicators have been considered in the analysis. Those two social media are the most widely used and the conclusions that we have advanced are conditioned by those limitations.

\section{Conclusions}

The main purpose of this work is to know the perception that the managers have about the application of marketing management at their ski resorts. To do this, an internal marketing audit is carried out, applying the importance-performance analysis, incorporating methodological innovations. In particular, the ROC (receiver operating characteristic) curve is used to find the optimal location of discriminating thresholds. This identifies what is done better and what is done worse. Respectively, the following have been achieved:

\subsection{Conclusions about Marketing Audit}

\section{The Most and the Least Important Aspects of Ski-Resort Marketing}

The directors considered that both the opinions and the needs of the visitors were of the greatest importance, as was responding to legislative changes. They also considered it important to use the Internet in their strategies and to know their competitive positions and possible threats and opportunities. With regard to the organization, they highlighted the importance of defining their jobs and their characteristics, the relations between the marketing department and the others, and the training of marketing personnel. Finally, with regard to functions, the importance given to a well-positioned web site was high on the list, as were service-quality orientation, and both online and offline communications. Tracking the activities of other ski resorts or the implementation of a resort's own marketing and communication activities were not among the priorities. This situation confirms why the questions of tracking the activities of other ski resorts, periodically studying the social impact of the resort, and the availability of a clear, well-defined, and well-known mission statement are all among the questions considered of least importance. Among those questions are the availability of a corporate identity manual, cost reviews, controlling the achievement of objectives, employer motivation, having integrated marketing communications, and relations with co-workers.

It should be mentioned that looking for sustainable alternatives is not among the priorities. There is no clear orientation towards sustainable management or interest in social impact. For this 
reason, it is important to promote the awareness of sustainable development and management of ski resorts to maintain their attractiveness, as well as to be aware that overexploitation can downplay interest in the station.

\section{The Best and the Worst Marketing Performance at the Ski-Resorts}

At all times from the perspective of the directors of the ski-resorts, the factors that achieved a higher level of implementation were: The use of the Internet in the strategy and the availability of a well-positioned web; responding to legislative changes; monitoring economic changes in the local environment; knowing their position in relation to the other resorts, and the opinions of their visitors; well-defined marketing jobs and solid training; good relations between the marketing department and other departments; and a clear service orientation.

At the other extreme is the definition of objectives and their follow-up (referring to communication, the search for new segments, tracking other ski resorts, controlling the achievement of marketing objectives, social impact studies of their services); communications and marketing actions (availability of a manual on corporate identity, an internal communications system, carrying out direct marketing activities from databases or online, adopting integrated communications), and relations (review the efficiency of tour operators).

In general, the dimensions of the environment and the organization were considered to lead to higher performance levels than the functional dimensions, above all those connected with tracking and control.

\section{The Weaknesses of Marketing at Ski-Resorts}

The greatest differences between importance and performance are the key deficits, or, expressed otherwise, the weaknesses in the very important questions. The greatest deficits arise principally in relation to the functions and have to do with:

- Employees: Need for motivation to achieve objectives;

- Market research: Research the needs of the target public; look for unexplored market segments or new market niches; deeper knowledge of the opinions of (real and potential) visitors;

- Communications: No adaptation to integrated marketing communications, no availability of and internal communications system, improvement of online and offline communications objectives;

- Activities to implement and relations: Database marketing activities, online, and direct; reviewing the efficiency of the tourism operators with which the resort collaborates; definition of a service quality strategy;

- Controlling objectives: Both for online and for offline marketing.

The greatest deficits were linked to employee motivation and communication.

Finally, there were, in general, no differences between the scores of the directors by country. The differences between the 32 items were all exceptions.

\subsection{Patterns of Behavior on Social Media of Ski Resorts}

The social media profiles of the Spanish and the Italian ski resorts have presented differences. Those of Italy were more active, had a more proactive behavior on Facebook, which was adapted largely to their communications strategy. These differences were significant for the following indicators: About, response, total page likes, and native Facebook videos. The resorts from both countries showed a similar behavior on Twitter, although the Italians had more following, tweets with mentions, and hashtags. The Spanish resorts, in this case with statistically significant differences, had more tweets, followers, and listed.

Four behavioral typologies were identified in these social media networks, which were average profile, inactive social media, leader, and aversion to Twitter. The Spanish ski resort of Sierra Nevada 
was the most active one, while the Italian resorts had a higher number in the group of aversion to Twitter. The Italians were more active on Facebook.

Author Contributions: T.L.M., L.D.T. and N.F. contributed equally to this work.

Funding: This research received no external funding.

Conflicts of Interest: The authors declare no conflict of interest. 


\section{Appendix A}

Table A1. Importance-performance scores. Differences between importance and performance and significance level of the Wilkinson's test for differences between importance and performance.

\begin{tabular}{|c|c|c|c|c|c|c|}
\hline \multirow{2}{*}{ List of items } & \multicolumn{2}{|c|}{ Importance I } & \multicolumn{2}{|c|}{ Performance P } & \multirow{2}{*}{ I-P } & \multirow{2}{*}{$\begin{array}{c}\text { Sig. Level } \\
\text { Wilcoxon Test for } \\
\text { Difference }\end{array}$} \\
\hline & Avg. & $\begin{array}{l}\text { Std. } \\
\text { Dev. }\end{array}$ & Avg. & $\begin{array}{l}\text { Std. } \\
\text { Dev. }\end{array}$ & & \\
\hline \multicolumn{7}{|l|}{ Marketing Environment } \\
\hline $\begin{array}{l}\text { The ski resort takes into account and takes action on the main } \\
\text { economic events in its environment }\end{array}$ & 7.72 & 1.73 & 7.14 & 2.279 & 0.31 & 0.153 \\
\hline $\begin{array}{l}\text { The ski resort looks for sustainable alternatives related to } \\
\text { environmental impact }\end{array}$ & 7.59 & 2.062 & 7.03 & 2.195 & 0.45 & 0.221 \\
\hline Annual investigation of the needs of the target public of the ski resort & 8.31 & 2.316 & 7.45 & 1.682 & 1.28 & 0.002 \\
\hline The ski resort knows the opinion of its (real and potential) visitors & 8.52 & 1.805 & 6.55 & 2.063 & 1.07 & 0.014 \\
\hline $\begin{array}{l}\text { Availability of information on objectives, strategies, strengths and } \\
\text { weaknesses of other ski resorts }\end{array}$ & 7.31 & 1.984 & 8.00 & 1.464 & 0.76 & 0.059 \\
\hline $\begin{array}{l}\text { The ski resort is aware of and rapidly responds to legislative changes } \\
\text { that may affect it }\end{array}$ & 8.28 & 1.533 & 7.07 & 1.534 & 0.28 & 0.297 \\
\hline $\begin{array}{l}\text { The ski resort takes into account the main technological changes of } \\
\text { its environment }\end{array}$ & 7.86 & 1.62 & 6.86 & 1.959 & 0.79 & 0.029 \\
\hline \multicolumn{7}{|l|}{ Marketing Strategy } \\
\hline $\begin{array}{l}\text { The mission is clearly expressed, is feasible and known to all } \\
\text { members of the organization }\end{array}$ & 7.48 & 2.246 & 6.86 & 1.959 & 0.62 & 0.165 \\
\hline Availability of a coherent and feasible marketing plan & 8.03 & 2.368 & 7.00 & 2.252 & 1.03 & 0.007 \\
\hline $\begin{array}{l}\text { The marketing strategy takes into account a realistic tourism load for } \\
\text { the ski resort }\end{array}$ & 7.69 & 2.173 & 7.00 & 2.138 & 0.69 & 0.048 \\
\hline The ski resort looks for new unsatisfied segments and market niches & 7.69 & 2.316 & 6.62 & 2.259 & 1.07 & 0.003 \\
\hline Availability of a manual on corporate identity & 7.28 & 2.658 & 6.45 & 3.019 & 0.83 & 0.077 \\
\hline $\begin{array}{l}\text { The strategy of the ski resort promotes good relations with its } \\
\text { stakeholder groups }\end{array}$ & 7.93 & 1.907 & 7.07 & 1.771 & 0.86 & 0.001 \\
\hline Internet forms part of the marketing strategy of the ski resort & 8.72 & 1.334 & 8.31 & 1.65 & 0.41 & 0.068 \\
\hline $\begin{array}{l}\text { The ski resort knows its competitive position and its threats and } \\
\text { opportunities, in order to define objectives }\end{array}$ & 8.31 & 1.391 & 7.66 & 1.587 & 0.65 & 0.008 \\
\hline
\end{tabular}


Table A1. Cont.

\begin{tabular}{|c|c|c|c|c|c|c|}
\hline \multirow{2}{*}{ List of items } & \multicolumn{2}{|c|}{ Importance I } & \multicolumn{2}{|c|}{ Performance $\mathbf{P}$} & \multirow{2}{*}{ I-P } & \multirow{2}{*}{$\begin{array}{c}\text { Sig. Level } \\
\text { Wilcoxon Test for } \\
\text { Difference }\end{array}$} \\
\hline & Avg. & $\begin{array}{l}\text { Std. } \\
\text { Dev. }\end{array}$ & Avg. & $\begin{array}{l}\text { Std. } \\
\text { Dev. }\end{array}$ & & \\
\hline \multicolumn{7}{|l|}{ Marketing Environment } \\
\hline \multicolumn{7}{|l|}{ Marketing Organization } \\
\hline $\begin{array}{l}\text { Well-defined jobs with objectives, responsibilities, and authority for } \\
\text { their development }\end{array}$ & 8.41 & 1.575 & 7.59 & 1.693 & 0.82 & 0.007 \\
\hline $\begin{array}{l}\text { Good relations and communications between the marketing } \\
\text { department and the other departments }\end{array}$ & 8.37 & 1.668 & 7.37 & 2.097 & 1 & 0.016 \\
\hline Participants in marketing activities are properly trained & 8.30 & 1.436 & 7.44 & 1.672 & 0.86 & 0.022 \\
\hline The employees are motivated to achieve the marketing objectives & 7.67 & 2.148 & 6.00 & 2.253 & 1.67 & 0.002 \\
\hline \multicolumn{7}{|l|}{ Marketing Systems } \\
\hline $\begin{array}{l}\text { The ski resort monitors the achievement of (off-line and on-line) } \\
\text { marketing objectives and evaluates the deviations }\end{array}$ & 7.59 & 2.341 & 6.22 & 2.455 & 1.37 & 0.001 \\
\hline The ski resort uses web analytics tools & 7.70 & 2.145 & 7.00 & 2.075 & 0.70 & 0.046 \\
\hline \multicolumn{7}{|l|}{ Marketing Productivity } \\
\hline The ski resort periodically studies the social impact of its services & 7.04 & 2.394 & 6.07 & 2.745 & 0.97 & 0.007 \\
\hline $\begin{array}{l}\text { The ski resort shares programmes through collaborative agreements } \\
\text { with other institutions }\end{array}$ & 7.78 & 1.739 & 6.96 & 1.99 & 0.82 & 0.014 \\
\hline $\begin{array}{l}\text { The cost of the marketing activities is periodically revised and } \\
\text { suitable measures are taken }\end{array}$ & 7.41 & 2.606 & 6.96 & 2.295 & 0.45 & 0.149 \\
\hline \multicolumn{7}{|l|}{ Marketing Functions } \\
\hline Availability of a well-positioned web site in the search engines & 8.37 & 1.668 & 7.63 & 1.597 & 0.74 & 0.017 \\
\hline Clearly defined service quality strategy & 8.30 & 1.589 & 7.11 & 1.867 & 1.19 & 0.004 \\
\hline The ski resort has a system of internal communication & 7.89 & 1.695 & 6.44 & 1.987 & 1.45 & 0.001 \\
\hline $\begin{array}{l}\text { The ski resort defines and is clear with regard to its on-line and } \\
\text { off-line communications objectives (publicity and promotion) }\end{array}$ & 8.22 & 2.044 & 6.85 & 2.196 & 1.37 & 0.002 \\
\hline $\begin{array}{l}\text { The services present some added value that differentiates it from } \\
\text { other ski resorts }\end{array}$ & 7.70 & 2.431 & 7.00 & 2.496 & 0.70 & 0.128 \\
\hline $\begin{array}{l}\text { The ski resort periodically reviews the efficacy of the tourist } \\
\text { operators and commercial companies with which it works }\end{array}$ & 7.41 & 2.664 & 6.19 & 2.617 & 1.22 & 0.003 \\
\hline $\begin{array}{l}\text { The ski resort performs direct marketing, online marketing, } \\
\text { and database marketing activities }\end{array}$ & 7.70 & 2.163 & 6.15 & 2.445 & 1.55 & 0.001 \\
\hline $\begin{array}{l}\text { Communications are adapted to the concept of integrated marketing } \\
\text { communication }\end{array}$ & 7.56 & 2.694 & 5.96 & 2.519 & 1.60 & 0.000 \\
\hline
\end{tabular}




\section{References}

1. Hall, J.; O'Mahony, B.; Gayler, J. Modelling the relationship between attribute satisfaction, overall satisfaction, and behavioural intentions in Australian ski resorts. J. Travel Tour. Mark. 2017, 34, 764-778. [CrossRef]

2. Weed, M. Why the two won't tango! Explaining the lack of integrated policies for sport and tourism in the UK. J. Sport Manag. 2003, 17, 258-283. [CrossRef]

3. Tjørve, E.; Lien, G.; Flognfeldt, T. Properties of first-time vs. repeat visitors: Lessons for marketing Norwegian ski resorts. Curr. Issues Tour. 2015, 21, 78-102. [CrossRef]

4. Matzler, K.; Sauerwein, L.; Heischmidt, K.A. Importance performance analysis revisited: The role of the factor structure of customer satisfaction. Serv. Ind. J. 2003, 23, 112-129. [CrossRef]

5. Matzler, K.; Füller, J.; Renzl, B.; Herting, S.; Späth, S. Customer satisfaction with Alpine ski areas: The moderating effects of personal, situational, and product factors. J. Travel Res. 2008, 46, $403-413$. [CrossRef]

6. García Lastra, Ó.; Escalera Izquierdo, G. Análisis longitudinal de los sitios web de las estaciones de esquí y montaña de España, Andorra y Pirineo de Francia. Temporadas 2009-10 y 2013-14. Cuadernos de Turismo 2016, 38, 171-194. [CrossRef]

7. Bausch, T.; Unseld, C. Winter tourism in Germany is much more than skiing! Consumer motives and implications to Alpine destination marketing. J. Vac. Mark. 2017. [CrossRef]

8. Tsiotsou, R. Using visit frequency to segment ski resorts customers. J. Vac. Mark. 2006, 12, 15-26. [CrossRef]

9. Abegg, B.; Agrawala, S.; Crick, F.Y.; Montfalcon, A. Effets des changements climatiques et adaptation dans le tourisme d'hiver. In Changements Climatiques dans les Alpes Européennes. Adapter le Tourisme D'hiver et la Gestion des Risques Naturels; Agrawala, S., Ed.; OCDE: Paris, France, 2007.

10. Lasanta, T.; Laguna, M.; Vicente-Serrano, S.M. Do tourism-based ski resorts contribute to the homogeneous development of the Mediterranean mountains? A case study in the Central Spanish Pyrenees. Tour. Manag. 2007, 28, 1326-1339. [CrossRef]

11. Miragaia, D.; Conde, D.; Soares, J. Measuring Service Quality of Ski Resorts: An Approach to Identify the Consumer Profile. Open Sports Sci. J. 2016, 9, 53-61. [CrossRef]

12. Pearce, D.G.; Schänzel, H.A. Destination management: The tourists' perspective. J. Dest. Mark. Manag. 2013, 2, 137-145. [CrossRef]

13. d'Hauteserre, A.M. Lessons in managed destination competitiveness: The case of Foxwoods Casino Resort. Tour. Manag. 2000, 21, 23-32. [CrossRef]

14. Miragaia, D.A.M.; Martins, M.A.B. Mix between satisfaction and attributes destination choice: A segmentation criterion to understand the ski resorts consumers. Int. J. Tour. Res. 2015, 17, 313-324. [CrossRef]

15. Kang, J.H.; Bagozzi, R.P.; Oh, J. Emotions as antecedents of participant sport consumption decisions: A model integrating emotive, self-based, and utilitarian evaluations. J. Sport Manag. 2011, 25, 314-325. [CrossRef]

16. Godfrey, K.B. Attributes of destination choice: British skiing in Canada. J. Vac. Mark. 1999, 5, 18-30. [CrossRef]

17. Matzler, K.; Siller, H.J. Linking travel motivations with perceptions of destinations: The case of youth travelers in Alpine summer and winter tourism. Tour. Rev. 2003, 58, 6-11. [CrossRef]

18. Clark, J.S.; Maher, J.K. If you have their minds, will their bodies follow? Factors effecting customer loyalty in a ski resort setting. J. Vac. Mark. 2007, 13, 59-71. [CrossRef]

19. World Congress on Snow and Mountain Tourism-WCSMT. Mountainlikers: Nuevas Tendencias del Turismo de Montaña en Verano, at the 8th Snow and Mountain World Congress, Andorra la Vella. 2014. Available online: http://www.congresdeneu.ad/ (accessed on 9 October 2018).

20. Kotler, P.; Dubois, B. Marketing Management; Publi Union: Paris, France, 1986.

21. Daries-Ramon, N.; Cristóbal-Fransi, E.; Martin-Fuentes, E.; Marine-Roig, E. Adopción del comercio electrónico en el turismo de nieve y montaña: Análisis de la presencia web de las estaciones de esquí a través del Modelo eMICA. Cuadernos de Turismo 2016, 37, 113-134. [CrossRef]

22. Quatman, C.; Chelladurai, P. Social network theory and analysis: A complementary lens for inquiry. J. Sport Manag. 2008, 22, 338-360. [CrossRef]

23. Calabuig Moreno, F.; Quintanilla Pardo, I.; Mundina Gómez, J. La calidad percibida de los servicios deportivos: Diferencias según instalación, género, edad y tipo de usuario en servicios náuticos. RICYDE Revista Internacional de Ciencias del Deporte 2008, 4, 25-43. [CrossRef] 
24. Goncalves, O.; Robinot, E.; Michel, H. Does it pay to be green? The case of French ski resorts. J. Travel Res. 2016, 55, 889-903. [CrossRef]

25. Falk, M. A dynamic panel data analysis of snow depth and winter tourism. Tour. Manag. 2010, 31, 912-924. [CrossRef]

26. Cristobal-Fransi, E.; Daries, N.; Serra-Cantallops, A.; Ramón-Cardona, J.; Zorzano, M. Ski tourism and web marketing strategies: The case of ski resorts in France and Spain. Sustainability 2018, 10, 2920. [CrossRef]

27. Steiger, R.; Mayer, M. Snowmaking and climate change: Future options for snow production in Tyrolean ski resorts. Mt. Res. Dev. 2008, 28, 292-298. [CrossRef]

28. Trawöger, L. Convinced, ambivalent or annoyed: Tyrolean ski tourism stakeholders and their perceptions of climate change. Tour. Manag. 2014, 40, 338-351. [CrossRef] [PubMed]

29. Rutty, M.; Scott, D.; Johnson, P.; Pons, M.; Steiger, R.; Vilella, M. Using ski industry response to climatic variability to assess climate change risk: An analogue study in Eastern Canada. Tour. Manag. 2017, 58, 196-204. [CrossRef]

30. Gerbaux, F.; Marcelpoil, E. Gouvernance des stations de montagne en France: Les spécificités du partenariat public-privé. La revue de Géographie Alpine 2006, 94, 9-19. [CrossRef]

31. Dickson, T.J.; Faulks, P. Exploring Overseas Snowsport Participation by Australian Skiers and Snowboarders. Tour. Rev. 2007, 62, 7-14. [CrossRef]

32. Morgan, N. Time for 'mindful' destination management and marketing. J. Dest. Mark. Manag. 2012, 1, 8-9. [CrossRef]

33. Milman, A.; Zehrer, A. Exploring visitor experience at a mountain attraction: The Nordkette mountain in Tirol, Austria. J. Vac. Mark. 2018, 24, 172-186. [CrossRef]

34. ATUDEM. Asociación Turística de Estaciones de Esquí y Montaña. 2015. Available online: http://www. atudem.org/ (accessed on 9 October 2018).

35. ATUDEM. Esquí España Dosier de Prensa Temporada 2017-2018. 2018. Available online: http://www. atudem.es/Products/00000001/MediaStatic/file/Dosier\%20Prensa\%202017\%202018\%20definitivo(1).pdf (accessed on 16 March 2019).

36. Confederazione Nazionale dell'Artigianato e della Piccola e Media Impresa (CNA). 2019. Available online: https://www.cna.it/ (accessed on 14 May 2019).

37. Kyle, G.T.; Theodorakis, N.D.; Karageorgiou, A.; Lafazani, M. The effect of service quality on customer loyalty within the context of ski resorts. J. Park Rec. Admin. 2010, 28, 1-15.

38. Kaplanidou, K.; Jordan, J.S.; Funk, D.; Ridinger, L.L. Recurring sport events and destination image perceptions: Impact on active sport tourist behavioural intentions and place attachment. J. Sport Manag. 2012, 26, 237-248. [CrossRef]

39. Jalilvand, M.R.; Samiei, N.; Dini, B.; Manzari, P.Y. Examining the structural relationships of electronic word of mouth, destination image, tourist attitude toward destination and travel intention: An integrated approach. J. Dest. Mark. Manag. 2012, 1, 134-143. [CrossRef]

40. Konu, H.; Laukkanen, T.; Komppula, R. Using ski destination choice criteria to segment Finnish ski resort customers. Tour. Manag. 2011, 32, 1096-1105. [CrossRef]

41. Ismert, M.; Petrick, J.F. Indicators and standards of quality related to seasonal employment in the ski industry. J. Travel Res. 2004, 43, 46-56. [CrossRef]

42. Hudson, S.; Shephard, G.W. Measuring service quality at tourist destinations: An application of importance-performance analysis to an alpine ski resort. J. Travel Tour. Mark. 1998, 7, 61-77. [CrossRef]

43. Hwa-Ryong, K.; Sung-Kyeom, K. Importance-Satisfaction Analysis of Attribute Assessment for Ski Resort. Korean J. Sports Sci. 2010, 19, 715-731.

44. Richards, G. Skilled consumption and UK ski holidays. Tour. Manag. 1996, 17, 25-34. [CrossRef]

45. Vassiliadis, C.A.; Priporas, C.V.; Andronikidis, A. An analysis of visitor behaviour using time blocks: A study of ski destinations in Greece. Tour. Manag. 2013, 34, 61-70. [CrossRef]

46. Komppula, R.; Laukkanen, T. Comparing perceived images with projected images-A case study on Finnish ski destinations. Eur. J. Tour. Res. 2016, 12, 41-53.

47. Verma, V.; Sharma, D.; Sheth, J. Does relationship marketing matter in online retailing? A meta-analytic approach. J. Acad. Mark. Sci. 2016, 44, 206-217. [CrossRef]

48. Scott, J. Social Network Analysis; Sage: Thousand Oaks, CA, USA, 2017.

49. Global Digital Report. 2018. Available online: https://digitalreport.wearesocial.com/ (accessed on 15 September 2018). 
50. Chen, Y.; Wang, Q.; Xie, J. Online social interactions: A natural experiment on word of mouth versus observational learning. J. Mark. Res. 2011, 48, 238-254. [CrossRef]

51. Zhang, M.; Jansen, B.J.; Chowdhury, A. Business engagement on Twitter: A path analysis. Electron. Mark. 2011, 21, 161-172. [CrossRef]

52. Lipsman, A.; Mudd, G.; Rich, M.; Bruich, S. The power of "like": How brands reach (and influence) fans through social-media marketing. J. Advert. Res. 2012, 52, 40-52. [CrossRef]

53. Nelson-Field, K.; Riebe, E.; Sharp, B. What's Not to "Like?": Can a Facebook Fan Base give a Brand the Advertising Reach it needs? J. Advert. Res. 2012, 52, 262-269. [CrossRef]

54. Hur, W.M.; Ahn, K.H.; Kim, M. Building brand loyalty through managing brand community commitment. Manag. Decis. 2011, 49, 1194-1213. [CrossRef]

55. Sicilia, M.; Palazón, M. Brand communities on the internet: A case study of Coca-Cola's Spanish virtual community. Corp. Commun. Int. J. 2008, 13, 255-270. [CrossRef]

56. Baena, V. Online and mobile marketing strategies as drivers of brand love in sports teams: Findings from Real Madrid. Int. J. Sports Mark. Spons. 2016, 17, 202-218. [CrossRef]

57. Ioakimidis, M. Online marketing of professional sports clubs: Engaging fans on a new playing field. Int. J. Sports Mark. Spons. 2010, 11, 2-13. [CrossRef]

58. Hur, Y.; Ko, Y.J.; Valacich, J. A structural model of the relationships between sport website quality, e-satisfaction, and e-loyalty. J. Sport Manag. 2011, 25, 458-473. [CrossRef]

59. Luna-Nevarez, C.; Hyman, M.R. Common practices in destination website design. J. Dest. Mark. Manag. 2012, 1, 94-106. [CrossRef]

60. Viren, P.P.; Vogt, C.A.; Kline, C.; Rummel, A.M.; Tsao, J. Social network participation and coverage by tourism industry sector. J. Dest. Mark. Manag. 2015, 4, 110-119. [CrossRef]

61. Massa, P.; Avesani, P. Trust-aware recommender systems. In Proceedings of the 2007 ACM Conference on Recommender Systems, Minneapolis, MN, USA, 19-20 October 2007; pp. 17-24.

62. Gretzel, U.; Hwang, Y.H.; Fesenmaier, D.R. A behavioural framework for destination recommendation systems design. Dest. Recom. Syst. 2006, 64, 53-66.

63. Buhalis, D.; Law, R. Progress in information technology and tourism management: 20 years on and 10 years after the Internet-The state of eTourism research. Tour. Manag. 2008, 29, 609-623. [CrossRef]

64. Martilla, J.A.; James, J.C. Importance-Performance Analysis. J. Mark. 1977, 41, 77-79. [CrossRef]

65. Ábalo Piñeiro, J.; Varela Mallou, J.; Rial Bubeta, A. El análisis de importancia-valoración aplicado a la gestión de servicios. Psicothema 2006, 18, 730-737.

66. Luque, T.; del Barrio, S. Análisis del valor de las percepciones de los clientes en el diagnóstico estratégico de la universidad. In Proceedings of the International Congress Marketing Trends, Paris, France, 26-27 January 2007; pp. 26-27.

67. Rial Boubeta, A.; Grobas Farto, A.; Braña Tobio, T.; Varela Mallou, J. ¿Tenemos realmente una universidad de calidad? Una evaluación cualitativa a partir del Análisis IPA segmentado. REMA Revista Electrónica de Metodología Aplicada 2012, 17, 32-50.

68. Del Barrio García, S.; Luque Martínez, T.; Rodríguez Molina, M.Á. La modelización de la imagen de ciudad desde la perspectiva de los líderes de opinión externos. EURE (Santiago) 2009, 35, 9-28. [CrossRef]

69. Levenburg, N.M.; Magal, S.R. Applying importanceeperformance analysis to evaluate e-business strategies among small firms. E-Serv. J. 2005, 3, 29-48. [CrossRef]

70. Azzopardi, E.; Nash, R. A critical evaluation of importance-performance analysis. Tour. Manag. 2013, 35, $222-233$. [CrossRef]

71. Server, I. Importance-performance analysis: A valid management tool? Tour. Manag. 2015, 48, 43-53. [CrossRef]

72. Bacon, D.R. A Comparison of Approaches to Importance-Performance Analysis. Int. J. Mark. Res. 2003, 45, 55-71. [CrossRef]

73. Lai, I.K.W.; Hitchcock, M. Importance-performance analysis in tourism: A framework for researchers. Tour. Manag. 2015, 48, 242-267. [CrossRef]

74. Dimanche, F.; Andrades, L. Methodological issues in cross-cultural tourism and hospitality research. In Handbook of Research Methods for Tourism and Hospitality Management; Edward Elgar Publishing: Cheltenham, UK, 2018. 
75. Alpert, M. Identification of determinant attributes a comparison of methods. J. Mark. Res. 1971, 8, $184-191$. [CrossRef]

76. Abalo, J.; Varela, J.; Manzano, V. Importance values for importancee performance analysis: A formula for spreading out values derived from preference rankings. J. Bus. Res. 2007, 60, 115-121. [CrossRef]

77. Youden, W.J. Index for rating diagnostic tests. Cancer 1950, 3, 32-35. [CrossRef]

78. Tkaczynski, A.; Rundle-Thiele, S.R.; Beaumont, N. Segmentation: A Tourism Stakeholder View. Tour. Manag. 2009, 30, 169-175. [CrossRef]

79. Andrades, L.; Dimanche, F. Destination competitiveness in Russia: Tourism professionals' skills and competences. Int. J. Contemp. Hosp. Manag. 2019, 31, 910-930. [CrossRef]

80. Buhalis, D.; Foerste, M. SoCoMo marketing for travel and tourism: Empowering co-creation of value. J. Dest. Mark. Manag. 2015, 4, 151-161. [CrossRef]

81. Zehrer, A.; Hallmann, K. A stakeholder perspective on policy indicators of destination competitiveness. J. Dest. Mark. Manag. 2015, 4, 120-126. [CrossRef]

(C) 2019 by the authors. Licensee MDPI, Basel, Switzerland. This article is an open access article distributed under the terms and conditions of the Creative Commons Attribution (CC BY) license (http://creativecommons.org/licenses/by/4.0/). 